\title{
REVIEW
}

\section{Perspectives on mucus secretion in reef corals}

\author{
B. E. Brown* , J. C. Bythell \\ School of Biology, Newcastle University, Newcastle upon Tyne NE1 7RU, UK
}

\begin{abstract}
The coral surface mucus layer provides a vital interface between the coral epithelium and the seawater environment and mucus acts in defence against a wide range of environmental stresses, in ciliary-mucus feeding and in sediment cleansing, amongst other roles. However, we know surprisingly little about the in situ physical and chemical properties of the layer, or its dynamics of formation. We review the nature of coral mucus and its derivation and outline the wide array of roles that are proposed for mucus secretion in corals. Finally, we review models of the surface mucus layer formation. We argue that at any one time, different types of mucus secretions may be produced at different sites within the coral colony and that mucus layers secreted by the coral may not be single homogeneous layers but consist of separate layers with different properties. This requires a much more dynamic view of mucus than has been considered before and has important implications, not least for bacterial colonisation. Understanding the formation and dynamics of the surface mucus layer under different environmental conditions is critical to understanding a wide range of associated ecological processes.
\end{abstract}

KEY WORDS: Mucin · Mucopolysaccharide · Coral surface microlayer · CSM · Surface mucopolysaccharide layer $\cdot \mathrm{SML}$

\section{INTRODUCTION}

The study of mucus secretion by corals has fascinated scientists for almost a century, from the work of Duerden (1906), Yonge (1930) Marshall \& Orr (1931) to the present day. Even so, our understanding of the composition, production and roles of mucus, its inter- and intra-specific variability over time and energetic significance remains fragmentary. This seems surprising given that mucus is produced to a greater or lesser extent by all corals, and it is essential for vital processes such as heterotrophic feeding and sediment cleansing and as a defence against a multitude of environmental stresses. Much of the earlier work looked at the functions and composition of mucus in a limited number of scleractinian corals as well as the trophic significance of mucus production for other coral reef organisms. As trends in reef science changed direction in the mid to late twentieth century, with implications of climate change for coral reefs assuming an increasingly important focus, interest in physiological processes such as mucus production diminished. Indeed copious mucus production has been a problem for many working with coral tissues in recent years, and the offending substance has to be removed before histological, biochemical or physiological processing can begin.

The problems of defining mucus were highlighted by Crossland (1987). Many of the inconsistencies relating to its composition were attributed by Crossland to the interpretation of the term 'mucus', which has been used to describe the polysaccharide-protein complex released at the surface of the coral through to the aged, mucus aggregates found in reef systems. Such aggregates may include a great range of materials such as zooxanthellae, coral tissues, bacteria, nematocysts, plankton, filamentous algae and sediments (Crossland 1987, Wild et al. $2004 a, b)$. In this review mucus (sensu stricto) refers specifically to the polysaccharide protein lipid complex secreted by corals at their surface, unless otherwise stated. This complex has also been variously described as the coral surface microlayer (CSM), the surface mucopolysaccharide layer (SML) and the mucopolysaccharide layer (MPSL) by those working on microbial communities that live on the surface of corals (see Kellogg 2004). 
We feel that it is time that the study of mucus was revisited for at least 3 reasons. Firstly, mucus plays an important part in coral disease which has been responsible for significant coral mortality, particularly in the Caribbean (Porter et al. 2001) and more recently in the Indo-Pacific provinces (Sutherland et al. 2004). In this context mucus may function both as a protective physicochemical barrier (Peters 1997, Santavy \& Peters 1997, Hayes \& Goreau 1998, Sutherland et al. 2004) and as a growth medium for bacteria, including potential pathogens (Ducklow \& Mitchell 1979b, Rublee et al. 1980, Toren et al. 1998, Banin et al. 2001, Lipp et al. 2002). But what do we actually know about the dynamics of the in situ mucus layer or its physico-chemical properties that might influence bacterial entrainment, growth or inhibition? Apparently we know very little. Even the most fundamental measure, the rate of mucus production, is extremely difficult to assess and is poorly defined in the literature. When, for example, authors report increased mucus production rates due to environmental stress, is this actually an increase in synthesis or merely an increase in the release of stored mucus?

Secondly, coral algal symbionts play an important role in governing the composition of mucus, with 20 to $45 \%$ of daily net photosynthate being released as mucus and dissolved organic carbon (Davies 1984, Crossland 1987, Bythell 1988, Edmunds \& Davies 1989). It follows then that during bleaching, when densities of algal symbionts are significantly reduced, both the composition and secretion of mucus may be markedly affected. Algal symbionts are also responsible in some corals for the production of sunscreens (the mycosporine-like amino acids), which are secreted into the mucus layer as a protection against harmful ultraviolet radiation (UVR) (Drollet et al. 1993, Shick et al. 1995, 1996. In bleached corals any interference with heterotrophic feeding capability (through modification of mucus involved in muco-ciliary feeding) or reduction in sunscreen protection might have serious implications for recovery processes, particularly since it is at this time that particulate feeding and UVR protection are essential for survival. Deprived of autotrophic sources of nutrition, we might ask whether bleached corals do indeed produce mucus that is significantly different in form and function from that in healthy corals, and if so what the downstream consequences of any induced changes might be?

Some of the tools that might be helpful in answering these questions lie in the third reason for re-visiting mucus secretion in corals - namely the advances that have been made in recent years in medical investigations of mucus. New experimental techniques have revolutionised how mucus can be observed both 'in vivo' (Atuma et al. 2001) and in preserved material using freeze substitution and confocal laser micro- scopy (Marshall \& Wright 1993, Marshall \& Clode 2004). The physical properties of mucus have been redefined using deformation rheology (i.e. the behaviour of a substance under compression) (Taylor et al. 2003), and the thickness of the mucus layer determined using special histological techniques (Jordan et al. 1998, Strugala et al. 2003). The chemical composition of mucus has been studied and important constituents of mucus - the mucin glycoproteins - have been characterised using density centrifugation, and gel filtration chromatography (Dixon et al. 2001), while genes have been sequenced that regulate production of specific mucins (Porchet \& Aubert 2004). Advances in membrane biophysics are revolutionising the understanding of the physics and of water and ion exchange functions in the respiratory mucosa (Verdugo 1990) of vertebrates. Changes in the state of mucus (from fluid to a gel) could be regulated by the exchange of ions and water across the respiratory epithelium, offering the possibility that other physiological controls maybe operating via secretory cells in vertebrates and mucus secreting cells in corals. Such developments offer a fertile ground for collaboration in elucidating the structure and function of coral mucus in the twentyfirst century.

The aim of this review then is to look again at what is known about coral mucus and its physical and chemical properties in the light of these recent medical findings. We also briefly summarise the multiple functions that mucus may play in corals and the observed variability in its production, both between and within species. We provide a conceptual framework for mucus production in corals in order to rationalise and compare different measures of mucus production and release. Finally we highlight what we think are important questions which need to be asked in future research.

\section{THE NATURE OF MUCUS AND ITS DERIVATION}

\section{Composition of mucus}

Coral mucus is a complex mixture of materials, the composition of which varies temporally (Crossland et al. 1980, Crossland 1987), between coral species (Miekle et al. 1988), with depth and/or irradiance (Crossland 1987) and with ageing and contamination upon release into the seawater environment (Ducklow \& Mitchell 1979a,b, Daumas et al. 1982, Coffroth 1990, Wild et al. 2004a,b). Critically, the question of whether there are different types of mucus, perhaps associated with different ecological functions, has barely been addressed. While several early studies highlighted confusion over the definition of mucus and different methods of analysis and thus different chemical com- 
ponents that were included, the methods of mucus collection also varied (Table 1) and may have selected for different types of mucus. Because released mucus becomes contaminated with sediment, micro-organisms, and particulates released by the coral, many workers have used artificial stresses such as air exposure and physical stimulation to induce mucus release in order to obtain 'pure' mucus. However, the relationship between the composition, form, and function of mucus released during such artificial stresses and under normal conditions is not known. Several workers have noted differences in the content of mucus collected by artificially stressing the coral compared to that collected in situ. Gottfried \& Roman (1983) suggested that the organic content of mucus collected by stressing the coral was much higher $(76$ to $82 \%$ ashfree dry weight, AFDW) than mucus collected in situ (9 to $60 \%$ AFDW). However, mucus production differs between and within coral species. Coffroth (1990), for example, showed that poritid corals can produce both a fluid mucus (78\% AFDW) and mucous sheets (32\% AFDW). In subsequent work Coffroth (1991) coated a glass slide with fluid mucus and noted that it was transformed to a mucous-sheet-like structure over a period of $6 \mathrm{~d}$ upon incubation in seawater. Coffroth proposed that such a physico-chemical change could take place in the field when mucus secretion or water movement over the coral surface was reduced.

The most elegant methods used to date to collect mucus produced by corals under near-natural conditions in situ are the flow-through chambers of Crossland (1987). His method of collection was coupled with capture of organic exudates onto diatomaceous earth (Celite) filters, which allowed estimates of particulate and dissolved organic carbon release, the latter being separated into mucus-polysaccharide and a dissolved organic carbon (DOC)-lipid fraction. The relationship between the DOC-lipid and mucus-polysaccharide components was believed to be a physical, rather than chemical association, but the rate of DOC-lipid release was about 3 to 4 times that of mucus-polysaccharide. Wild et al. $(2004 \mathrm{a}, \mathrm{b})$ have similarly reported that 56 to $80 \%$ of mucus released is dissolved, although no compositional analysis of the dissolved versus 'gel-like' fractions was carried out in this study.

Elemental composition of mucocytes and discharged mucus has been described for a limited number of corals (Kinchington 1982, Marshall \& Wright 1995). Recent work on freeze-substituted coral tissues has shown marked differences in the elemental composition of mucocytes in oculinid corals and those in the ahermatypic coral Tubastrea faulkneri (Marshall \& Wright 1995). Freeze substitution is a histological preparation method described in Marshall \& Wright (1991) which permits the microstructure of undecalcified and chemically untreated corals to be examined free of preparation artefacts. Subsequent X-ray microanalysis of mucocytes from 3 related oculinid corals (Galaxea fascicularis, G. astreata and Achrelia horrescens) revealed high concentrations of sulphur (S), potassium (K) and strontium (Sr). Levels of these elements in mucocytes from freeze-substituted tissues (expressed as units of embedded tissues) were 2 to 3.5 mol kg${ }^{-1} \mathrm{~S}, 1$ to $2 \mathrm{~mol} \mathrm{~kg}^{-1} \mathrm{~K}$ and 0.6 to $2.4 \mathrm{~mol} \mathrm{~kg}^{-1} \mathrm{Sr}$, together with substantial concentrations of calcium ( 300 to $\left.500 \mathrm{mmol} \mathrm{kg}^{-1}\right)$ and barium ( 200 to $600 \mathrm{mmol}$ $\mathrm{kg}^{-1}$ ). Mucocytes of Tubastrea contained low concentrations of $\mathrm{S}$ (700 $\mathrm{mmol} \mathrm{kg}^{-1}$ ), no $\mathrm{Sr}$, very low concen-

Table 1. Different methods of generation and collection of mucus for compositional analysis

\begin{tabular}{|c|c|}
\hline Method of mucus generation and collection & Source \\
\hline Air exposure (natural tidal exposure) & $\begin{array}{l}\text { Daumas et al. (1982), Wild et al. (2004a,b) } \\
\text { (for production rate determination) }\end{array}$ \\
\hline $\begin{array}{l}\text { Air exposure (experimental), sometimes with added } \\
\text { filtered seawater washes }\end{array}$ & $\begin{array}{l}\text { Coles \& Strathmann (1973), Benson \& Muscatine (1974), Ducklow \& } \\
\text { Mitchell (1979a), Krupp (1982), Coffroth (1990), Vacelet \& } \\
\text { Thomassin (1991), Wild et al. (2004a,b) (for compositional analysis) }\end{array}$ \\
\hline Sediment application & Mitchell \& Chet (1975) \\
\hline Water jets (submerged) & Benson \& Muscatine (1974), Richman et al. (1975), Rublee et al. (1980) \\
\hline Refrigeration $\left(4^{\circ} \mathrm{C}\right)$ under toluene & Meikle et al. $(1987,1988)$ \\
\hline $\begin{array}{l}\text { Syringe collection of mucous sheet or 'web' from } \\
\text { coral surface }\end{array}$ & Coles \& Strathmann (1973), Ducklow \& Mitchell (1979a), Coffroth (1990) \\
\hline $\begin{array}{l}\text { Coral held in incubation chamber and seawater } \\
\text { collected (laboratory aquarium) }\end{array}$ & Crossland et al. (1980), Means \& Sigleo (1986) \\
\hline $\begin{array}{l}\text { Coral held in incubation chamber and seawater } \\
\text { collected (field enclosure) }\end{array}$ & Richman et al. (1975), Crossland (1987) \\
\hline
\end{tabular}


trations of $\mathrm{K}$ and $\mathrm{Ca}$ but high concentrations of $\mathrm{Br}$ $\left(200 \mathrm{mmol} \mathrm{kg}^{-1}\right)$. The ratio of $\mathrm{K}: \mathrm{Sr}$ in G. fascicularis varied in mucocytes samples in different epithelial layers. Marshall \& Wright (1995) interpreted this variation as indicating differences in the composition of the mucus polymer or to different transport properties of the mucocyte or granule membranes. With our limited understanding of the dynamics of mucocyte development and turnover, it is perhaps premature to ascribe too much significance to these preliminary findings. Analysis of extruded coral mucus indicated that the ions associated with intracellular mucus were not present or were present in much lower concentrations. In addition, extruded mucus had a much lower affinity for $\mathrm{Sr}, \mathrm{Ca}$ and Ba than intracellular mucin granules (Marshall \& Wright 1995).

For the greater part, few workers studying coral mucus composition have focussed on the primary constituents of the mucus matrix - the glycoproteins or mucins. The one exception is the isolation of the sulphated glycoprotein MUC-3CPB from the coral Acropora muricata by Meikle et al. (1987). In human mucus the mucins make up to 10 to $100 \mathrm{mg} \mathrm{g}^{-1}$ wet weight of the mucus gel, with water making up $950 \mathrm{mg} \mathrm{g}^{-1}$ (Strugula et al. 2003). The characteristic viscoelastic properties of mucus are directly or indirectly determined by the presence of mucins which have been extensively studied by those interested in human pulmonary clearance. Verdugo (1990) notes that the features which determine the characteristics of mucus are the size, shape and charge of mucins. Mucins are highly heterogeneous glycoproteins that consist of a filamentous protein core to which short polysaccharide side-chains are attached. The core amounts to about $20 \%$ of the polymer by weight, and the remaining $80 \%$ is carbohydrate. The core contains cysteine residues, which are susceptible to cleavage, a process which is thought to occur during dispersion of mucus (Verdugo 1990). In addition, oligosaccharide side chains are linked to the core by O-glycosidic bonds between threonine and serine in the backbone and N-acetylgalactosamine on the sugar chains. Side-chains are 2 to 20 monosaccharides long, can be linear or branched and vary vastly in composition, and they are often sulphated and/or contain sialic terminals. In A. muricata the side-chains consisted of arabinose, D-mannose and $\mathrm{N}$-acetyl-D-glucosamine with smaller amounts of D-galactose, L-fucose and N-acetyl-D-galactosamine but no sialic or uronic acids (Meikle et al. 1987). The sulphated or sialic terminals confer upon mucus its characteristic polyionic properties and have important implications for mucus hydration. By controlling the secretion of mucins, $\mathrm{pH}$ and the transepithelial movement of electrolytes and water, the coral tissues, just like the vertebrate mucosa, should be able to broadly modulate not only the amount of mucus secreted at a site but also the rate of mucus swelling and its behaviour under compression.

\section{Sites of mucus secretion}

Several cell types have been described in human epithelia which contribute to mucus secretion (Verdugo 1990). However, in coral tissues, where detailed histological and histochemical studies are limited, mucus secretion has been primarily ascribed to a single cell type-the mucocyte (Marshall \& Wright 1993, Goldberg 2002). This is not to say that this is the only cell type responsible for mucus secretion, rather the mucocyte is the only cell which has been identified with mucus production in corals. Several other gland cells have been identified in coral tissues (Kinchington 1982, Le Tissier 1987), but their roles are unknown. It may be that these gland cells are special secretory cells or developing mucocytes, since similar gland cells have been observed to transform into mucous cells in vertebrate tissues (Sleigh et al. 1988). Semi-quantitative measures of the area occupied by mucocytes in the oral ectoderm of selected corals, using histological sections, reveal that these cells account for as much as $90 \%$ of the areal extent of the ectoderm in some areas of tissue (authors' unpubl. work) (Fig. 1A).

Where detailed histology has been carried out, with appropriate tissue preparation, mucocytes have been identified in all tissue layers of 2 of the 3 corals examined (Marshall \& Wright 1993). In Galaxea fascicularis large mucocytes ( 10 to $20 \mu \mathrm{m}$ length) dominate the outer oral ectoderm, particularly at the oral end of the polyp, where they are more numerous (Fig. 1B). They are club-shaped cells with basally oriented nuclei and large granular inclusions. The apical region of these cells has a circular aperture-like area, which has been described as possibly arising from the overlapping apical regions of surrounding ectodermal cells. Large mucocytes are also found in the oral gastroderm, where they surround the zooxanthellae and occupy a considerable volume of the tissue. The granules in these cells are larger than those in the ectodermal mucocytes.

The aboral gastroderm harbours mucocytes smaller ( $\sim$ to $10 \mu \mathrm{m}$ length) than those in the oral gastroderm, but they are similar in structure. Generally, they are less numerous than those in the oral gastroderm, and the granules are smaller. The narrow calicoblastic ectoderm contains relatively few small mucocytes, though close to the tip of exert septa there are numerous mucocytes. In the ahermatypic coral Tubastrea faulkneri mucocytes are particularly abundant in the calicoblastic ectoderm, where they appear to be inti- 


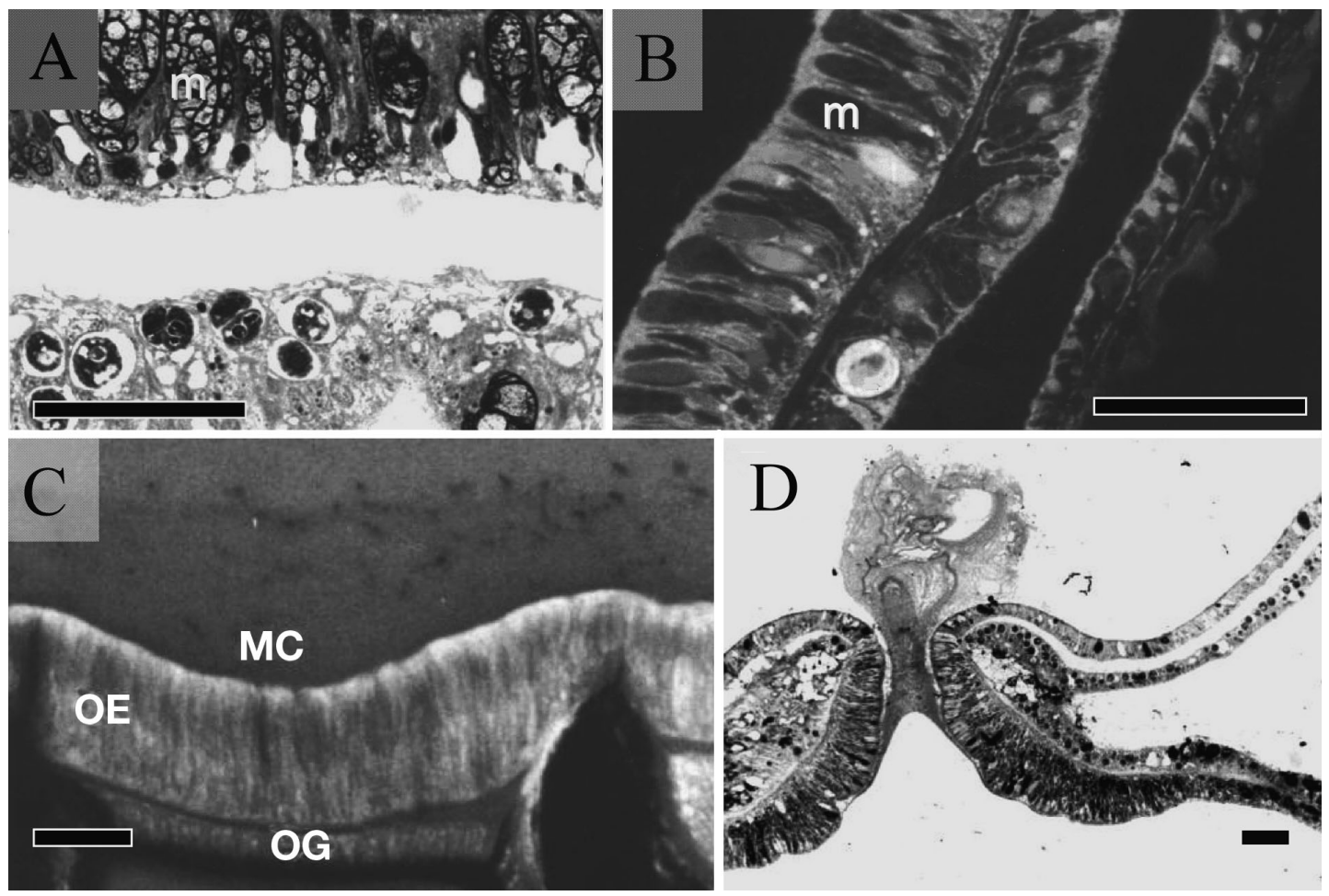

Fig. 1. (A, B) Histological sections showing abundant mucocytes (m) in the outer ectoderm of Goniastrea aspera and Galaxea fasicularis respectively. (C) The surface mucus layer (MC) as preserved by freeze-substitution techniques in Acropora muricata. OE: outer ectodermis; OG: outer gastrodermis. (D) Mucus plug extruding through the mouth in Goniastrea aspera. Scale bars $=50 \mu \mathrm{m}$. (B) and (C) were adapted from Marshall \& Wright (1993)

mately connected with the skeleton (Marshall \& Wright 1993).

The above pattern of mucocyte distribution is not universal, though it should be noted that few corals have been studied in detail. In apical polyps of Acropora formosa (now re-named $A$. muricata by Wallace 1999) no mucocytes were noted in the oral ectoderm, though there was a thick layer of mucus on the surface of the ectoderm (Marshall \& Wright 1993) (Fig. 1C). These findings, however, are in contrast with those of Isa \& Yamazato (1981), who describe mucous cells in the epithelial tissues of apical polyps of A. hebes. Interestingly, Marshall \& Wright (1993) do note numerous mucocytes in the oral ectoderm of parts of $A$. muricata colonies which are more basal in location. These fragmentary observations highlight the possible extreme variation in abundance and location of mucus-secreting cells both within a single colony and also within and between species. One explanation of such variation may lie, in part, in our total ignorance of the dynamics of mucocyte development and turnover. It is interesting to note that in histological sections of the mouth region of coral polyps of several faviid species mucus has been observed lining the ectoderm and apparently 'streaming' out of the mouth (Fig. 1D) (authors' unpubl. work).

\section{Physical properties of mucus and its rheology}

Mucus rheology (its behaviour under compression) is a scientific discipline which has been studied primarily in vertebrates (Verdugo 1990), yet it is fundamental to the understanding of both the form and function of mucus in all organisms. The rheological properties of mucus are central to its exudation and subsequent hydration, to its swelling and annealing, to its formation of a transport medium and finally to its dispersion. While some attempts have been made to understand the rheology of the pedal mucus of gastropod molluscs (Ronkin 1955, Kwart \& Shashoua 1957, Hunt \& Jevons 1966, Grenon \& Walker 1980), no similar studies have ever been made in corals.

In the study of human mucus it had been originally supposed that different cells produced different secretions, which were then blended to produce a gel of suitable viscosity. It is now believed that mucous cells release their secretions in a condensed form, which then undergoes a massive swelling on hydration. It is only after this hydration that the mucins (the polymer chains that are so important in determining the physiochemical properties of the mucus gel) are mixed and annealed to form a visco-elastic gel. The rheological properties are 
not determined by the blending of secretions of different fluidity, as originally supposed, but probably by controlling transepithelial movement of water and ions that hydrate different secretory products (Verdugo 1990).

In this way it is possible to create more watery or alternatively more viscous secretions, which could result in the 2-component layers described in human mucous secretions. It is interesting to note that as early as 1906 Duerden described a 2-phase system in the mucus layer of corals, with that adjacent to the ectoderm being described as clear, colourless and watery, while the more superficial layer was more membranelike. Such a system is very similar to that in the human respiratory mucus described by Sleigh et al. (1988), particularly the model of Ross \& Corrsin (1974), who noted a water periciliary layer and an outer viscoelastic layer. More recent in vivo observations of human intestinal mucus suggest, however, an innermost layer of firmly adherent gel and an outer layer of sloppy constituency in this secretion (Atuma et al. 2001). Such findings have enormous significance for coral mucus, not only in providing a graded medium for bacterial populations but also in wound healing and satisfying the wide array of potential functions described in the following sections.

\section{Bacterial populations in the coral mucus layer}

There is mounting evidence that the bacterial community developing on the surface of the coral is distinctly different to that of the water column overlying it (Cooney et al. 2002, Frias-Lopez et al. 2002). Such results suggest that the coral microflora represents a set of microbial communities that have developed in situ due to a (presumably wide) range of available niches, rather than it representing the passive settlement of water-borne micro-organisms onto the coral surface. However, does the surface mucus layer (the surface mucopolysaccharide layer or SML; see Ritchie \& Smith 2004) act as a concentrator, a growth medium or a barrier to bacteria and other micro-organisms?

Several workers have noted an abundance of bacteria in coral mucus flocs and organic aggregates derived from mucus in the water column (Johannes 1967). Coffroth (1990) showed that bacterial densities on mucous sheets produced by Porites spp. were approximately 2 to 3 times that found in the adjacent $1 \mathrm{~cm}$ seawater layer, but this is not overly impressive given that mucous sheets are produced on an approximately lunar cycle in these species. Coffroth (1990) noted that the bacterial contribution to total carbon content of mucous sheets was relatively low $(<0.1 \%)$ and suggested that the decreased carbon:nitrogen $(\mathrm{C}: \mathrm{N})$ ratio of aged versus freshly secreted mucus may be due to loss of carbohydrates rather than bacterial $\mathrm{N}$ enrichment. Conversely, Ritchie \& Smith (2004) note that the SML contains 100 times the number of culturable bacteria than that of the surrounding seawater and that they are several orders of magnitude more metabolically active (Ritchie \& Smith 2004).

Oligotrophic tropical seas are typically depleted in nutrients and organic matter. It is therefore not surprising that released mucus can form an important substrate for microbial growth (Moriarty et al. 1985, Linley \& Koop 1986, Paul et al. 1986, Wild et al. 2004a,b). Since most ( 56 to $80 \%$ ) of the mucus is composed of a dissolved organic matter (DOM) fraction, it might be expected to be readily available for microbial biomineralisation. However, there is some controversy about the suitability of mucus as a microbial substrate. Vacelet \& Thomassin (1991) argued that the bacterial load in mucus, although higher than in seawater, was not as great as would be expected given the 27- to 155-fold higher carbon concentration. They also showed that a visible mucus web remained intact after $3 \mathrm{wk}$ of incubation in dialysis bags in the field, indicating that the material was not readily accessible and/or that the mucus contained bacterial inhibitors. A higher bacterial growth rate was observed on diluted rather than pure mucus, indicating that the effect was mainly due to inhibitors (Vacelet \& Thomassin 1991). It is interesting that the recent study by Wild et al. $(2004 a, b)$ showed that mucus remineralisation occurs mainly as a result of the activity of interstitial micro-organisms in lagoonal sediments, rather than in the water column immediately adjacent to the coral colony.

Two recent reviews have proposed theoretical models of coral surface mucus layer stratification and structure due to mucus release by the coral and microbial colonisation and metabolic activity (Ritchie \& Smith 2004, Rohwer \& Kelley 2004; Fig. 2). Ritchie \& Smith (2004) describe a theoretical stratification based on microbial remineralisation of organic exudates that may render the central layers of the SML microaerophilic or even anaerobic, an hypothesis that is supported by recent culture-independent studies showing a significant proportion of anaerobic archaea in the SML (Kellogg 2004). Their model (Fig. 2, upper panel) depends on the microbial community maintaining its position within the mucus layer as organic exudates are passed through the layer and consumed by the bacterial community. Rohwer \& Kelley (2004) argue further that corals may be able to control the bacterial colonies that inhabit the SML by altering the composition of the mucus. In this way growth of beneficial bacteria, for example, nitrogen fixers or those that inhibit potential pathogens, could be promoted. Their model and supporting histological evidence (Fig. 2, lower panel) indicate a microbial community developing as separate colonies on the outer 'surface' of the SML. 


\section{THE FUNCTIONS OF CORAL MUCUS}

Scrutiny of the literature suggests that corals display a more diverse use of mucus than any other invertebrate. The principal roles of mucus in invertebrates have been documented as defence, feeding and locomotion (Denny 1989). In corals, not only are the functions of mucus within defence and feeding various, but mucous secretions may also be involved in an array of additional processes essential to the well-being of the coral. These include desiccation resistance, sediment shedding, calcification mechanisms, sunscreen protection, reproduction, settlement behaviour and possibly quenching of harmful oxygen radicals as described for mammalian mucosa (Cross et al. 1984).

\section{Mucus as an aid to heterotrophic feeding}

Coral mucus plays a major role in ciliary feeding. Yonge (1940) once described corals as having the greatest feeding surface area, relative to volume, of any organism in the animal kingdom. The efficiency of this surface in delivering food into the mouths of individual polyps is dependent on mucociliary transport. Uniformly arranged cilia cover the oral ectoderm, though there may be considerable variation in the extent of ciliary surfaces on coral colonies (Carlgren 1905). Sleigh (1989) suggests that mucus does not penetrate between cilia upon an active ciliated epithelium to any extent, although it is sometimes drawn down between the cilia when they are non-mobile. During transport, only the ciliary tip penetrates the lower surface of the mucus on the mid part of the effective stroke. Since the cilia only penetrate the highly viscous mucus at their extreme tip, there is localised resistance to movement, which tends to bend the cilia backwards. This effect explains the restricted length of cilia involved in mucus transport (5 to $7 \mu \mathrm{m})$. The reduced length of cilia and the short ciliary beat means that the rates of mucus transport are modest, being no greater than 100 to $200{\mu \mathrm{s}^{-1}}^{-1}$ Cilia that propel mucus do not work alone but as members of a metachronal wave. Even a small raft or flake of mucus would be likely to be propelled by several metachronal waves (Sleigh et al. 1988). Any food particles trapped by the mucous surface are carried by mucociliary transport to the mouth of the coral polyp and then into the pharynx, where they are digested. Spungin \& Silberberg (1984), working with vertebrate preparations, maintain that mucus is secreted in response
Fig. 2. Models of surface mucus layer (SML) formation and microbial community development and utilisation. Reproduced with permission from Ritchie \& Smith (2004) (top panel) and Rohwer \& Kelly (2004) (bottom panel). In both cases, the question of how quickly the SML turns over is critical to an understanding of these processes. In both cases a gap is hypothesised between the coral surface and the microbial community. Rohwer \& Kelly (2004) support this model (A) with SEM (B) and histological micrographs (C). M: mucocytes; Z: zooxanthellae 
to the presence of particles, with ciliary beating being stimulated by the presence of mucus.

Early coral workers, such as Duerden (1906), described the importance of mucus secretion and ciliary currents in transfer of food particles to the mouths of coral polyps, and even suggested that the physical composition of mucus used in feeding was different from that used in discarding non-nutritive particles. Mucus deployed in feeding was described as watery, while that involved in polyp cleaning was membranelike. He further describes the inhalent currents set up by ciliary action which carry food in mucous rafts to the mouth to be ingested. In subsequent work Yonge (1930) discussed, in great detail, the feeding mechanisms shown by Atlantic and Pacific corals. He highlighted the importance of mucociliary feeding in these species and mentions the use of mucus strings in many small-polyped varieties to capture food. The strings are then conveyed to the mouth by mucociliary action. Other workers (Lewis \& Price 1975, Lewis 1977, Goldberg 2002) showed that several Atlantic corals species were able to act as suspension feeders by means of mucous nets and strands, which were subsequently drawn into the mouth. Lewis (1977) argued that the ability of reef corals to feed by mucous nets greatly increased the potential food resource available to them. This resource includes not only zooplankton but also suspended particulate material, which might involve bacterio-plankton, bacterial aggregates (Sorokin 1973, Bak et al. 1998) and other fine particulates, such as silts and fine sands (Mills \& Sebens 1997). Anthony (1999), working with corals from the Great Barrier Reef, has shown that suspended particulate matter feeding, at high particle concentrations, can account for up to half the carbon and one third of the nitrogen required for tissue growth in certain corals. Feeding rates of 0.75 to $1.07 \times 10^{9}$ bacterial cells $100 \mathrm{~cm}^{-2} \mathrm{~h}^{-1}$ in the Caribbean coral Madracis madracis translate into a nitrogen input of 3 to $4 \mathrm{nmol} \mathrm{N} \mathrm{cm}{ }^{-2} \mathrm{~h}^{-1}$, which could be 30 to $45 \%$ of a particulate feeding pattern (Bak et al. 1998). While the authors acknowledge that these rates of feeding may not represent typical or maximum rates of bacterial suspension feeding in these organisms, they do indicate the potential significance of microbial communities in coral nutrition.

Another benefit of ingestion of a mucus net or strand by the coral is that it reclaims a significant expenditure of energy. Crossland et al. (1980) claim that as much as $40 \%$ of all carbon fixed by symbiotic algae in Acopora acuminata goes into mucus production. Other estimates vary depending on the species studied and their location on the reef - for shallow-water Stylophora pistillata, about $20 \%$ of the daily photosynthate may be released as mucus and DOC lipid, while for Acropora variabilis at $5 \mathrm{~m}$ the loss was estimated as $8 \%$ (Crossland 1987). In the Caribbean coral Porites porites, as much as $45 \%$ of the energy fixed was assumed to be lost as mucus secretion (Edmunds \& Davies 1986). Whatever the figure, it may be advantageous for the coral to reclaim as much of this expended energy as possible, and this could be achieved by ingestion of feeding nets, strings and strands. It should be noted, however, that the exact amount of mucus produced and lost by the majority of corals is still unknown, as is its energetic significance.

\section{Mucus as a defence against a potentially hostile environment surrounding the coral}

\section{Defence against pathogens}

Various properties of mucus may aid in defending underlying coral tissues from bacterial attack. These include acting as a physical barrier to the microbial content of surrounding seawater (Cooney et al. 2002); aiding mucociliary transport of particles to the polyp mouth, where microbes can be digested (Sorokin 1978, Ducklow 1990); sloughing off and protecting colonisation by potentially pathogenic bacteria (Ducklow \& Mitchell 1979a, Rublee et al. 1980); and serving as a medium into which allelochemicals, which have an anti-bacterial role, may be exuded (Slattery et al. 1995, 1997, Koh 1997, Kelman et al. 1998).

The anti-bacterial functions of coral mucus are particularly well documented in the soft corals. Overall, anti-microbial activity has been shown to be highly variable in these corals, with whole-tissue extracts from some species showing no inhibitory effect on marine bacteria, and only 4 out of 39 species showing strong inhibitory effects using disk-diffusion assays (Jensen et al. 1996). Similarly, Astley \& Ratcliffe (1989) showed antibacterial activity against only 2 out of 10 bacterial species tested against extracts from mucus of the sea anemone Metridium senile. However, Kim (1994) showed antibacterial activity in most gorgonian extracts. Slattery et al. (1995) demonstrated anti-microbial and anti-fouling activity in Antarctic soft corals and suggested that, although mucus secretion in these species was low, it was likely to be important in preventing bacterial attachment to the coral surface. Interestingly, the antibacterial activity shown appears to be very specific. For example, in the Red Sea soft coral Paerythropodium fulvum fulvum, no anti-bacterial activity was observed against coralassociated bacterial strains isolated from coral tissue and its mucoid surface. Very high activity was found, however, against Vibrio sp. isolated from necrotic coral tissue (Kelman et al. 1998). These authors argue 
that such specificity may be necessary to allow particular bacteria to live in close association with the host while others are deterred. Certainly, bacterial populations living naturally in coral mucus have been widely reported (Di Salvo 1973, Trench 1974, Mitchell \& Chet 1975, Rublee et al. 1980, Segel \& Ducklow 1982). Ducklow \& Mitchell (1979b) noted that bacterial populations living in coral mucus were viable, functional and also very closely attuned to the physiological state of their hosts. This is an interesting observation given that there are circumstances where mucus may aid in the attachment of pathogenic micro-organisms to the coral surface. The mechanisms by which pathogens penetrate the mucosa of the gut and respiratory tract of humans have been relatively well studied. In particular, the mucolytic activity of pathogens is higher than that of benign bacteria (Deplancke et al. 2002). In corals, little is known about the behaviour of pathogenic bacteria within the mucus layer. One exception is the infection of the Mediterranean coral Oculina patagonica by Vibrio shiloi, a pathogen that targets the symbiotic algae of the coral (Kushmaro et al. 1997, 1998, Rosenberg \& Ben-Haim 2002). Banin et al. (2001) demonstrated that $V$. shiloi showed positive chemotaxis towards and adhered to coral-mucus preparations. Adhesion was inhibited by methyl- $\beta$-Dgalactopyranoside, indicating that a $\beta$-D-galactoside receptor present in the mucus was involved in adhesion. Adhesion of the pathogen to corals was reduced following mucus depletion and in corals without symbiotic algae or in which symbiont photosynthesis had been inhibited with 3-(3,4-dichlorophenyl)-1,1dimethylurea (DCMU). In this case it therefore appears that the pathogen uses components of the mucus to gain entry to the coral.

The active agents in coral mucus which cause antibacterial activity have received limited study. In Antarctic soft corals homarine was identified as a metabolite in the antibacterial fraction (Slattery et al. 1997), while in the Red Sea soft coral antimicrobial activity was due to a variety of secondary compounds of different polarities (Kelman et al. 1998). Novel bioactivities of coral mucus have also been noted in the scleractinian coral Galaxea fascicularis, where purified components of mucus showed a DNAse-like activity and apoptotic activity against a multiple drug-resistant leukemia cell line (Ding et al. 1999) and contained a novel antitumour compound which inhibited Topoisomerase I and II (Fung \& Ding 1998). In the tropical soft coral Dendronephytya, it has been shown that the bacterial strains inhabiting the colony surface contribute to antifouling mechanisms through the production of heat-stable polysaccharides with a molecular weight of $>100 \mathrm{kDa}$ (Dobretsov \& Quian 2004).
Defence against space invasion by other corals

Mucus secretion plays an important role in the acquisition of space in some coral species such as the free-living fungiid corals (Chadwick 1988). In Fungia scutaria nocturnally expanded polyps may deposit a layer of mucus up to $15 \mathrm{~mm}$ thick onto neighbouring corals. Released into this mucous layer are many nematocysts, including microbasic mastigophores, holotrichous izorhizas and spirocysts. The mucous layer may remain in contact with neighbouring corals for up to $6 \mathrm{~d}$, during which significant damage may be done either directly by the nematocysts or indirectly through tissue suffocation and bacterial attack. During the first day following contact, coral polyps under the mucous layer were still intact. Within $2 \mathrm{~d}$ these coral tissues began to decay and micro-organisms invaded the mucus. By 4 to $6 \mathrm{~d}$ time the mucus had sloughed off and exposed bare coral skeleton. Superficially similar responses occur in xenografts between Fungia spp. and other reef corals (Hildemann et al. 1975, 1977, Bigger et al. 1984).

The initiation of interactions between corals may occur through a number of mechanisms including the recognition of molecules in secreted mucus (Lang \& Chornesky 1990). Sauer et al. (1986), working with the sea anemone Anemonia viridis, isolated a glycoprotein with a molecular weight of 12 to $14 \mathrm{kDa}$ that caused tentacular deflation and acrorhagial inflation, and they claimed that this mucus-bound compound elicited aggressive behaviour without contact between anemones. However, Shick (1991) noted that the tentacles were frozen along with the mucus during the extraction of the glycoprotein in this experiment and therefore the active component could equally have been bound to the cell surface. It is clear that the exact nature of stimuli involved in competitive interactions between corals remains elusive. Recent work with nudibranch molluscs (Greenwood et al. 2004) has shown that they are capable of producing mucus which inhibits nematocyst discharge from anemone prey. When the prey was changed to another anemone species, the nudibranch mucus also changed within 2 wk to inhibit the nematocyst discharge by the new prey species. Greenwood et al. (2004) noted that sea anemones do not sting themselves or clone-mates and hypothesised that they may produce compounds which prevent nematocyst discharge that are yet to be identified. It is interesting to note that some of the most aggressive corals on Indo-Pacific reefs are among the most copious mucus producers. Species such as Fungia scutaria and Galaxea fascicularis are well known for their abundant mucus secretion, though Fungia scutaria secretes large quantities of mucus even when not in contact with other species. 


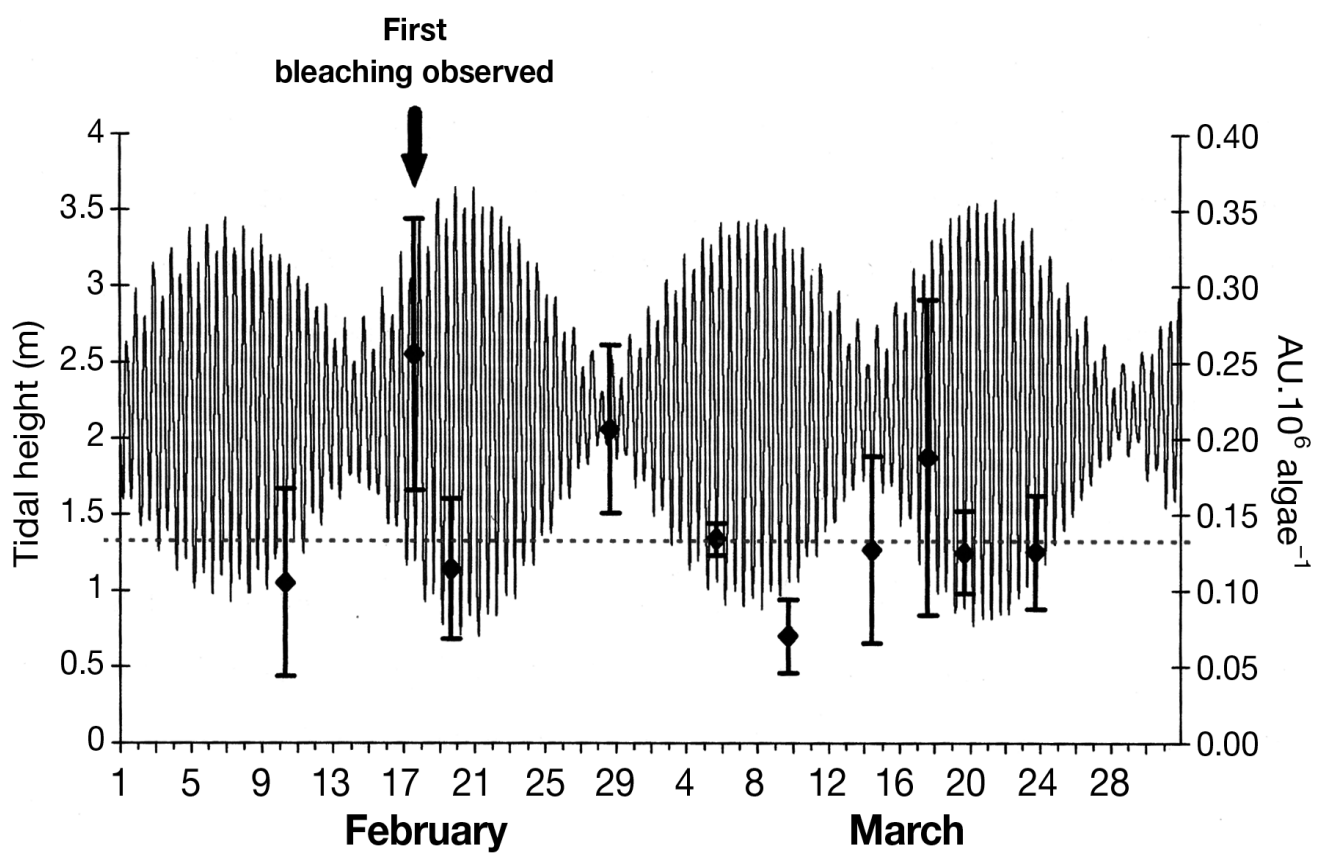

Fig. 3. Absorbance at $324 \mathrm{~nm}$ by UV-absorbing compounds extracted from symbiotic algae isolated from intertidal Goniastrea aspera colonies collected over the course of 4 spring tides at Phuket, Thailand, in 1996, during a solar bleaching event (after Hawkridge 1998). Diamonds represent means \pm SD $(n=10)$ and are superimposed on a plot of tidal height during the period. Dotted line: tidal height when colonies were exposed above water

\section{Defence against UVR damage}

Another role of mucus, through substances secreted into it, is in protection of underlying coral tissues from UVR. Drollet et al. (1993) measured the UV absorbance spectrum of mucus exuded from Fungia fungites in French Polynesia following aerial exposure of the coral. They found evidence of UV-absorbing compounds in the mucus, the concentration of which was maximal during the first 2 min of secretion and then decreased thereafter. In subsequent work Drollet et al. (1997) identified the UV absorbing compounds as mycosporine-2-glycine, palythine and mycosporineglycine. In an 18 mo monitoring period during which mucus was collected weekly, they claimed that the amount of UV-absorbing compounds present correlated significantly with the flux of incident solar radiation but with a lag of $1 \mathrm{wk}$. Shifts in the wavelength of maximum absorbance of the mucus during the study were attributed to a 6 -fold increase in the concentration of mycosporine-2-glycine and a 3- to 4-fold increase in palythine and mycosporine-glycine and were tentatively linked to incident solar radiation. These authors also claimed that the concentration of mycosporine-like amino acids (MAAs) in the mucus reflected the concentration and production of these compounds in the tissues. In subsequent work Teai et al. (1997) studied 23 species of corals from French
Polynesia and found between 4 and 7 MAAs in different corals. They showed that most specimens of the same species possessed the same pattern of MAAs. Although species from the same genus had a similar complement of MAAs, the actual quantities of individual MAAs varied from specimen to specimen. Furthermore, reductions in MAA concentrations in some species were attributed to the effects of bleaching. Such results highlight the likelihood that the composition of mucus, with respect to MAAs, varies markedly between coral colonies and also with environmental circumstances. Analysis of MAAs in zooxanthellae of the coral Goniastrea aspera, supposedly a major source of MAA production in some corals (Shick et al. 1996), revealed marked variation in MAA levels over tidal cycles that one might assume from the above literature to be reflected in the mucus (Fig. 3) (Hawkridge 1998). In related work Banaszak \& Trench (1995) concluded that the coral algal symbiont Symbiodinium microadriaticum synthesised MAAs, which were then transported to the animal host. Subsequently, Banaszak et al. (2000) showed that Phylotype A Symbiodinium spp. had a high predilection for synthesis of MAAs, while Phylotypes B and C did not. However, these results should be viewed with caution, since only cultured algae were considered and the authors admitted that their sampling was biased towards Phylotype A Symbiodinium. 
Defence against desiccation

While it is widely recognised that corals produce mucus on exposure to air and that such secretions will act as protection against desiccation (Daumas \& Thomassin 1977, Krupp 1984), the mechanisms by which this is achieved are less certain. Krupp (1984) argued that since mucus is extremely hydroscopic it would act to maintain moisture on the surfaces of corals during exposure to air. Denny (1989) noted that the secretion of mucus in gastropod molluscs exposed to air dried quickly, forming a stiff thin wall that sealed off the underlying soft tissues from the air above. He noted that it was unlikely the mucous layer was impermeable to water because it could be rapidly rehydrated. However, in limpets the mucous layer greatly reduces the flow of air and also reduces the rate of water exchange with rates of evaporative loss being only $14 \%$ of that when the mucus was removed experimentally (Woollcott 1973). In aerially exposed anemones Shick (1991) argued that mucus presents little barrier to diffusion of water, but it may produce a boundary layer as it dries and separates from the outer tissues (Griffiths 1977).

Defence against smothering by sediment

Mucociliary transport not only aids feeding but also acts to remove non-nutritive particles from the coral surface. It is a common mechanism in several invertebrates for cleansing surfaces where secreted mucus that entraps particulate detritus is swept over the ciliated surface to some site of disposal (Sleigh 1989). Duerden (1906) was one of the first to experimentally demonstrate the movement of mucus-bound, nonnutritive particles to the edge of the disc of fungiid corals, where they fell to the substrate below.

Qualitative observations of increased mucus secretion in corals due to sedimentation are widespread in the literature (Bak \& Elghershuizen 1976, Schumacher 1977, Rogers 1990, Stafford-Smith \& Ormond 1992, Stafford-Smith 1993). With repeated influxes of sediment, the mucus-secreting cells of Fungia species have been inferred as becoming 'exhausted', finally causing sediment rejection to slow down and cease (Schumacher 1977). However, in other species, such as Gardinoseris planulata, mucus secretion continues long after sediment-rejection activity has ceased, suggesting that it is exhaustion of the ciliary mechanism rather than mucus secretion which occurs in this coral (Stafford-Smith 1993).

More recently, Reigl \& Branch (1995) have attempted to measure the energetic drain of mucus cleansing on corals. They looked at 4 scleractinian and 5 alcy- onacean corals and concluded that mucus secretion in sediment clearing was energetically very costly. Under sediment stress, carbon requirements for mucus secretion more than doubled. Mucus adhering to sediment was equivalent to 0.5 (Favia favus) to 3.5 (Sinularia dura) days' worth of photosynthetic production. Similar conclusions were reached by Edmunds \& Davies (1989), who suggested that the secretion of mucus by sediment-stressed Porites porites constituted an important route for energy loss.

During an experimental manipulation, Coffroth (1985) found that fine particulate sedimentation did not significantly increase the frequency of mucous sheet formation in either Porites furcata or P. astreoides. Mucuous sheet formation can, however, be induced by increased sediment accumulation in $P$. furcata. These results were obtained in corals manipulated in chambers, and Coffroth (1985) highlights the fact that reduction of water movement also resulted in mucous-sheet formation. She comments that mucous sheet formation may be a secondary mechanism to cope with sediment stress, especially when currents are not strong enough to alleviate environmental conditions.

Defence against pollutants and other stresses

Increased mucus secretion has been described in response to exposure to pollutants such as crude oil (Mitchell \& Chet 1975, Neff \& Anderson 1981), copper sulphate (Mitchell \& Chet 1975), mercury (Bastidas \& Garcia 2004), fish-collecting chemicals (Jaap \& Wheaton 1975), drilling muds (Thompson et al. 1980), peat (Dallmeyer et al. 1982), increased water temperatures (Neudecker 1983) and decreased salinity (Coffroth 1985). In histological studies an increase in the number and size of mucous secretory cells was observed as a result of exposure of the Caribbean coral Manicina areolata to chronic oil pollution (Peters et al. 1981).

The variability in mucus secretion by different coral species is well illustrated in their response to pollutants. In experiments with drilling muds, Thompson et al. (1980) showed that colonies of Acropora cervicornis produced mucous strands after 30 min exposure, whereas mucus production by other species (Porites divaricata, P. furcata, P. astreoides and Montastraea annularis) was not observed until $24 \mathrm{~h}$ after mud application. Similarly exposure of Acropora muricata to a 5 to $6^{\circ} \mathrm{C}$ temperature increase at the Cabros Power Plant in Guam resulted in considerable mucus production within a few hours but no excessive mucus secretion in either Pocillopora damicornis or Porites andrewsi (Neudecker 1983). 
It has been suggested that mucus may bind or absorb pollutants such as aromatic hydrocarbons (Neff \& Anderson 1981) or heavy metals (Howell 1982, Howard \& Brown 1984, Brown \& Howard 1985) and so confer some protection to the underlying coral tissues either by physically protecting them or by acting as an avenue for pollutant release from contaminated corals (Neff \& Anderson 1981). As far as metals are concerned, Marshall (2002) concluded that there is no evidence to suggest that mucus in corals acts as a protection through metal binding. Although the mucus within mucocytes in sections of freeze-substituted tissues readily took up cadmium and zinc from solutions in which the tissues were floated, neither of these metals were detected in either mucocytes or mucus of corals which had been exposed to metals prior to freezing. However, without a better understanding of the turnover of mucocytes, or the mucus that they produce, we are still not in a position to demonstrate whether mucus plays any role in metal regulation.

\section{Defence against physical damage}

Although there has been extensive literature on the recovery of mechanically induced lesions in corals, there has been very little detailed description of whether mucus plays a role in the healing and regeneration of lesion areas (Meesters et al. 1994, 1996, 1997, Oren et al. 1997). Mucus secretion has been described as being induced by mechanical stresses from waves and currents, abrasion from sediments and scraping by invertebrates and fish grazing (Daumas \& Thomassin 1977). As early as 1967, Johannes (1967) stated that observations of corals in situ typically provides inconclusive evidence of mucus release, although he noted strings of visible mucus being released from Acropora sp., particularly near natural lesions. More recently, Bruckner \& Bruckner (2000) noted extensive release of mucus on fresh and expanding lesions associated with parrotfish bites. They observed no tissue sloughing, unlike that often observed in disease conditions, and lesions frequently regenerated if predation ceased.

\section{A possible role for mucus in calcification}

Mucocytes of 3 related species of corals, namely Galaxea fascicularis, G. astreata and Achrelia horrescens, have been shown to contain high concentrations of sulphur, potassium and strontium as well as substantial levels of calcium and barium (Marshall \& Wright 1995). Calcium is also a predominant cation in human mucus (see Marshall \& Wright 1995 for review).
Subsequent, more detailed work on the coral G. fascicularis during daytime has revealed higher concentrations of sulphur, potassium and calcium in the seawater layer (10 to $20 \mu \mathrm{m}$ thick) adjacent to the oral ectoderm than in standard sea water (Clode \& Marshall 2002). At night-time concentrations of calcium and sulphur in external sea water were significantly reduced compared with daytime values. Furthermore, calcium concentrations in the coelenteron and extrathecal coelenteron were significantly higher than in external sea water, irrespective of the time of sampling. Clode \& Marshall (2002) interpreted their results as evidence of calcium transport across the oral epithelium via an active mechanism. Their X-ray microanalysis of mucocytes, in freeze-substituted material, showed that while the concentration of sulphur was high and invariant across epithelial layers, that of calcium increased over an inward gradient towards the skeleton. The authors suggested that during the day secreted mucus behaves as a medium which maintains a Donnan equilibrium (i.e. a medium which separates an unequal distribution of diffusible ions between 2 ionic solutions) at the oral-sea-water interface facilitating calcium uptake.

It has also been proposed that some of the soluble components of the organic matrix of the coral skeleton, which is responsible for regulating crystal growth, might be derived from mucus extracts. Marin et al. (1996) detected a partial homology between the skeletal matrix and mucus in 2 bivalves and the scleractinian coral Galaxea fascicularis, while Goreau (1959) also proposed that calcium-binding, acid mucopolysaccharides were incorporated into the organic matrices of corals. Clode \& Marshall (2003), however, argued against these conclusions. While they accept that mucins in corals may be similar to those found in organic matrices, they maintain that it is unlikely that calicoblastic mucocytes are a primary source of the sulphated molecules in the skeletal matrix. The main reason for this thinking is that mucocytes are thinly distributed in calicoblastic tissues which cover areas of the skeleton where calcification is highest. They suggested it is probable that incorporation of mucus into the skeletal matrix occurs incidentally through small amounts of mucus being excreted into extracellular pockets on the calicoblastic ectodermskeleton interface.

\section{Mucus as a surfactant and as a lubricant}

Another function ascribed to coral mucus secretion by Deacon (1979) is that of reducing the wind-drag over coral reefs. Deacon noted that often in shallow atoll lagoons the water surface was unusually free of ripples, and he attributed this to the high concentration 
of ethyl palmitate in coral mucus, which, once hydrolysed, yielded a powerful surfactant that calmed the water surface and would be conducive to the growth of delicate corals.

Observations of corals flowering during daytime where extended polyps appear to 'go with the flow' of prevailing currents (e.g. Dendrogyra in the Caribbean and Goniopora and Euphyllia in the Indo-Pacific) suggest that mucus may also have some important lubricant properties.

While the above observations have never been quantified, they are included to illustrate the diverse nature of possible functions that have been ascribed to coral mucus.

\section{Mucus as an excretory pathway-the result of a high carbon diet?}

Davies (1984) first proposed that mucus release may function primarily as an excretory pathway for excess organic carbon produced via symbiont photosynthesis. The release of mucus may therefore be a direct consequence of nitrogen limitation and the 'low quality' (high $\mathrm{C}: \mathrm{N}$ ) diet provided to the host due to high levels of symbiont photosynthesis and rates of translocation to the host (78 to $97 \%$; Muscatine et al. 1984, Edmunds \& Davies 1986). Similar examples of carbon excretion are seen in other animals that process a highvolume/low-quality diet, for example, honeydew production in aphids feeding on sap (Llewellyn \& Qureshi 1979) and mucus production in the sea urchin Strongylocentrotus droebachiensis feeding on algal detritus (Field 1972). Mucus may include a significant protein- nitrogen component (Table 2), resulting in similar C:N ratio in the mucus to that of coral tissues, so its release would therefore be unlikely to be a consequence of a low quality diet. However, there are questions over the true composition of mucus released in situ (see above). Bythell (1988) showed using incubations with in situ chambers that the nitrogen loss via DOM release represented a greater proportion of the total nitrogen budget than the carbon loss did of the carbon budget, despite the high $\mathrm{C}: \mathrm{N}$ ratio (range of 61 to 76 ) of materials translocated to the host from the symbionts. It is possible that the major component of DOC-lipid release reported by Crossland (1987) represents an excretory pathway, while mucus polysaccharides fulfil physiological and ecological roles described earlier. Both DOC-lipid and mucus release showed a strong diurnal pattern, with maximal rates of release in the afternoon. However, this diurnal pattern was maintained even in corals taken from an ambient $32 \%$ irradiance at $5 \mathrm{~m}$ depth and shaded to $13 \%$ incident irradiance, an equivalent of $16 \mathrm{~m}$ depth. If the diurnal pattern represented 'luxury' carbon production being channelled into mucus/DOC release, then the pattern would be expected to break down as the excess production was reduced.

\section{Reproduction and larval settlement}

As well as serving a protective function, mucus performs other roles during reproduction and larval behaviour. A unique mode of reproduction, described as 'surface brooding', has been observed in the Red Sea soft coral Parerythropodium fulvum fulvum (Benayahu

Table 2. Basic compositional analysis of coral mucus. See Table 1 for various methods of mucus generation, collection and extraction. Analysis methods also vary substantially between workers

\begin{tabular}{|ccccccccl}
\hline $\begin{array}{c}\text { AFDW } \\
\text { mean } \\
(\%)\end{array}$ & $\begin{array}{c}\text { Lipid } \\
(\%)\end{array}$ & $\begin{array}{c}\text { Carbo- } \\
\text { hydrate } \\
(\%)\end{array}$ & $\begin{array}{c}\text { Protein } \\
(\%)\end{array}$ & $\begin{array}{c}\text { Particulates } \\
\text { removed? } \\
\text { centrifugation } \\
\text { or filtration) }\end{array}$ & $\begin{array}{c}\mathrm{C} \\
(\%)\end{array}$ & $\begin{array}{c}\mathrm{N} \\
(\%)\end{array}$ & C:N & Source \\
\hline 83 & 3.4 & 62 & 35 & Yes & 31 & 5.2 & 6.0 & Krupp (1982) \\
67 & 35 & 16 & 49 & No & & & & Ducklow \& Mitchell (1979a) \\
51 & 5.7 & $\begin{array}{c}2.0 \text { (glucose } \\
\text { equivalents) }\end{array}$ & 4.3 & No & 7.9 & 1.2 & 6.6 & Pascal \& Vacelet (1981) \\
89 & 4.7 & 23 & 41 & Yes & & & & \\
78 & 0.3 & 40 & 17 & No & 37 & 4.3 & 8.6 & Coffroth (1990) \\
80 & & & & No & 26 & 3.4 & 7.6 & Coles \& Strathmann (1973) \\
46 & & & & POM & & & & Richman et al. (1975) \\
22 & 38 & 21 & 41 & No & 0.52 & 0.04 & 13 & Daumas et al. (1982) \\
- & 93 & - & - & No & - & 1.6 & - & Daumas \& Thomassin (1977) \\
\hline
\end{tabular}


\& Loya 1983), where larvae actually develop in a protective mucous coat surrounding the parent colony. Similar surface brooding in mucus has also been observed in octocorals (Brazeau \& Lasker 1990, Gutierrez-Rodrigues \& Lasker 2004). In the Red Sea soft coral the fertilised eggs are attached to female colonies while entangled in a mucoid suspension. The mucus layer contains many sclerites, which are derived from the polyp during egg expulsion. In addition, the mucus contains various organic and inorganic particles. This covering remains on the surface of the colony for a week, during which time cleavage and then development of the planula larvae takes place. After $7 \mathrm{~d}$ the mucus and the now mature planulae detach from the coral surface and sink near the mother colony. The mucoid covering begins to degrade and the larvae become mobile. At this stage mucus secreted by the larvae adopts another role. During searching behaviour prior to settlement the larvae are attached to the substrate on their oral side by mucus, where it plays an important function in mucociliary locomotion. While it is likely that the planulae of many corals use mucusfacilitated locomotion in the searching phase (see Harrison \& Wallace 1990 for review), few accounts specifically mention involvement of mucus in this process. One exception is the study of settlement in Heliopora coerulea (Harii \& Kayanne 2003), where planulae were observed to crawl around using mucus.

Once searching behaviour is completed by the planula, settlement takes place by adhesion to the substrate. Although the mechanism of adhesion is poorly documented in the scientific literature, it is likely that this phase also involves mucus secretion. Histological investigation of the planula of the solitary coral Balanophyllia regia revealed the greatest number of gland cells at the aboral pole where adhesion occurs, while other workers have also noted that planulae of hydroids and sea pens secrete mucus at the onset of metamorphosis (Williams 1965, Chia \& Crawford 1973).

Clearly mucus plays a variety of roles during reproduction and settlement, with additional references to significant mucus production being made during release of planulae (Yonge 1940), eggs (Kojis \& Quinn 1981) and brooded polyps (Griffiths 1977), while planulae of the solitary coral Caryophyllia smithii trail mucous strings behind them to trap food particles (Tranter et al. 1982). Histological sections of reproductive polyps of the scleractinian coral Pavona cactus revealed a very large number of gland cells which were described in an 'active' state during early research by Marshall \& Stephenson (1933) on the Great Barrier Reef.

\section{A MODEL OF CORAL MUCUS PRODUCTION AND RELEASE}

In order to understand the ecological roles of coral mucus, we must first have a clear definition of the production and release processes (Fig. 4). As reviewed here, we know that the major proportion of photosynthetic carbon production is transferred to the host animal cells and stored as lipid (Fig. 4, Process 1). We also know that much of this material is released as a DOM fraction (Process 2), although whether or not this is secreted via the mucocytes and includes a mucopolysaccharide component remains unresolved (Process 3). While several workers refer to a 'dissolved mucus fraction' (e.g. Wild et al. 2004a,b), Crossland (1987) showed that the major carbon release was in the form of DOC-lipid. Mucus released to the coral tissue surface (Process 4) forms an intact layer that can be visualised using appropriate fixation and preservation techniques (Fig. 1; Marshall \& Wright 1993, Marshall \& Clode 2004). DOC released may diffuse through this layer and form gradients of organic carbon and oxygen due to microbial utilisation (Ritchie \& Smith 2004). However, while there is information on the rate of mucus release into the water column, particularly for the specific case of aerial exposure (Wild et al. $2004 a, b)$, the rate at which mucus is normally secreted to the coral surface is not known. In corals of the genus Porites the surface mucus layer forms with a lunar periodicity and ages to form a gel-like coat or tunic which subsequently sloughs away under wave action and water currents (Coffroth 1990) (Process 5). It is not known whether this is the general pattern of release, however, or whether the outer layers are continually eroded and ablated as fresh mucus is secreted via the

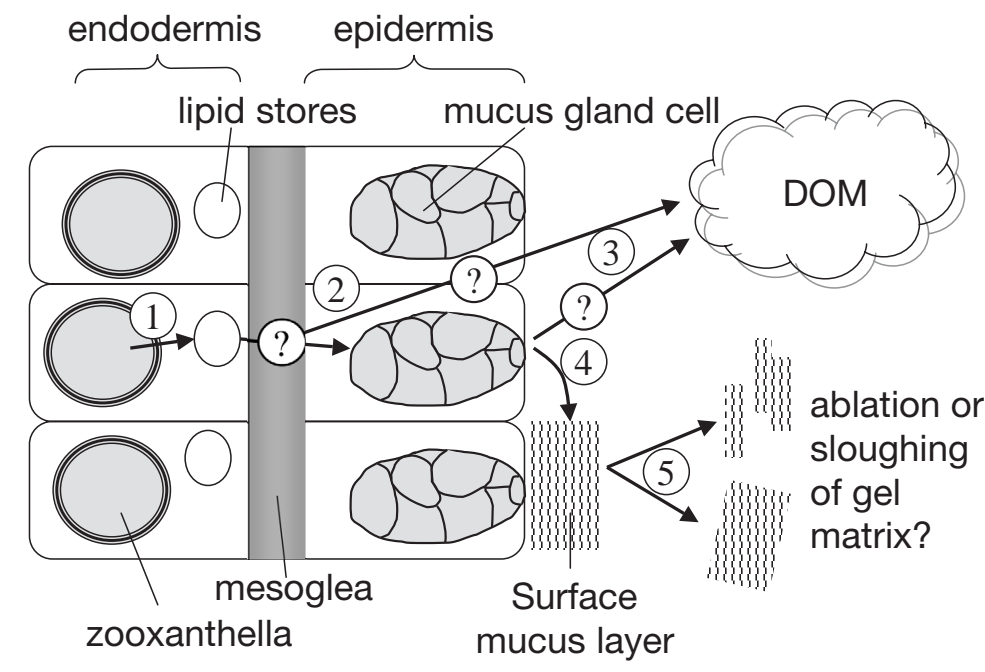

Fig. 4. Model of mucus secretion and release. See text for explanation of Processes 1 to 5 
mucocytes below. A better understanding of the dynamics of secretion and release of this surface layer will be critical to our understanding of microbial colonisation and the community development process.

\section{CONCLUSIONS}

The overall picture of mucus secretion appears then to be an extremely variable one, with temporal variation in mucus production between day and night (Crossland 1987) and at different times of the lunar cycle (Coffroth 1990). There is clearly also considerable variation in mucus composition and production both within and between species (Ducklow \& Mitchell 1979a, Crossland 1987, Meikle et al. 1988, Marshall \& Wright 1995). Given the array of functions performed by mucus in a single species of coral, it would seem unlikely that a single type of mucus could satisfy all needs. It is more probable that within a day a coral is able to vary the viscosity of mucus produced by the methods described earlier (e.g. by varying transepithelial transport of ions) and also the composition of mucus by mechanisms such as up-regulation of specific mucin genes and variable input of substances such as UVR protectants. It is likely that such variations are under environmental control, e.g. irradiance will influence both mucus composition and/or production rates in both predictable (diurnal variation) and unpredictable (exposure to high UVR) ways (Crossland et al. 1980, Crossland 1987, Drollet et al. 1997). It may also be that some alterations in mucus secretion are linked to the reproductive state of the coral as described in earlier sections of the review. As a result it is quite probable that at any one time different mucus secretions are being produced at different sites on and within the coral colony. Such a proposition requires a much more dynamic view of mucus than has ever been considered before. The possibility that mucus layers secreted both within and outside the coral are not single homogeneous layers at all but may be, in some cases, bilayers also requires investigation, for this has important implications, not least for bacterial colonisation. Fundamental to our future thinking about mucus is a re-evaluation of composition, form and physical properties of mucus secreted by different coral species under varying environmental conditions; sites of mucus secretion and rates of mucus synthesis and production. It will be essential to develop a suite of methodologies that allow rigorous, comparative analysis of these factors in a number of corals. Such studies pose considerable scientific challenges to the coral biologist, but the application of techniques used by medical physiologists, with their more comprehensive understanding of the form and structure of human mucus secretions and the properties of specific mucins, may well yield valuable insights into one of the least understood physiological processes in reef corals.

Acknowledgements. The authors would like to acknowledge Springer-Verlag and the authors concerned for allowing the inclusion of figures from their publications in Figs. $1 \& 2$.

\section{LITERATURE CITED}

Anthony KRN (1999) Coral suspension feeding on fine particulate matter. J Exp Mar Biol Ecol 232:85-106

Astley MR, Ratcliffe NA (1989) Marine invertebrate mucusagglutinating and antibacterial activity, with emphasis on Metridium senile. Symp Soc Exp Biol XLIII:367-377

Atuma C, Strugala V, Allen A, Holm L (2001) The adherent gastrointestinal mucus gel layer: thickness and physical state in vivo. Am J Physiol 280:G922-G929

Bak RPM, Elgershuizen JHBW (1976) Patterns of oil-sediment rejection in coral. Mar Biol 37:105-113

Bak RPM, Joenje M, de Jong I, Lambrechts DYM, Nieuwland G (1998) Bacterial suspension feeding by coral reef benthic organisms. Mar Ecol Prog Ser 175:285-288

Banaszak AT, Trench RK (1995) Effects of ultraviolet (UV) radiation on marine microalgal-invertebrate symbioses. II. The synthesis of mycosporine-like amino acids in response to exposure to UV in Anthopleura elegantissima and Cassiopeia xamachana. J Exp Mar Biol Ecol 194:233-250

Banaszak AT, LaJeunesse TC, Trench RK (2000) The synthesis of mycosporine-like amino acids by cultured, symbiotic dinoflagellates. J Exp Mar Biol Ecol 249:219-233

Banin E, Israely T, Fine M, Loya Y, Rosenberg E (2001) Role of endosymbiotic zooxanthellae and coral mucus in the adhesion of the coral-bleaching pathogen Vibrio shiloi to its host. FEMS Microbiol Lett 199:33-37

Bastidas C, Garcia EM (2004) Sublethal effects of mercury and its distribution in the coral Porites astreoides. Mar Ecol Prog Ser 267:133-143

Benayahu Y, Loya Y (1983) Surface brooding in the Red Sea soft coral Parerythropodium fulvum fulvum (Forskal, 1775). Biol Bull 165:353-369

Benson AA, Muscatine L (1974) Wax in coral mucus: energy transfer from corals to reef fishes. Limnol Oceanogr 19: 810-814

Bigger CH, Jokiel PL Hildemann WH (1984) Aspects of the maintenance of integrity by the solitary coral Fungia scutaria. In: Advances in reef science. Atl Reef Comm RSMAS Univ Miami and ISRS Joint Meeting, Miami, FL, p 10

Brazeau DA, Lasker HR (1990) Sexual reproduction and external brooding by the Caribbean gorgonian Briareum asbestinum. Mar Biol 104:465-474

Brown BE, Howard LS (1985) Assessing the effects of 'stress' on corals. Adv Mar Biol 22:1-63

Bruckner AW, Bruckner RJ (2000) Coral predation by Sparisoma viride and lack of relationship with coral disease. Proc 9th Int Coral Reef Symp 2:1245-1249

Bythell JC (1988) A total nitrogen and carbon budget for the elkhorn coral Acropora palmata (Lamarck). Proc 6th Int Coral Reef Symp 2:535-540

Carlgren O (1905) Über die Bedeutung der Flimmerbewegung für den Nahrungstransport bei den Actiarien und Madreporarien. Biol Zbl XXV:308-322

Chadwick NE (1988) Competition and locomotion in a freeliving fungiid coral. J Exp Mar Biol Ecol 123:189-200 
Chia FS, Crawford BJ (1973) Some observations on gametogenesis, larval development and substratum selection in the sea pen Ptilosarcus guerneyi. Mar Biol 23:73-82

Clode PL, Marshall AT (2002) Low temperature X-ray microanalysis of calcium in a scleractinian coral: evidence of active transport mechanisms. J Exp Biol 205:3543-3552

Clode PL, Marshall AT (2003) Calcium associated with a fibrillar organic matrix in the scleractinian coral Galaxea fascicularis. Protoplasma 220:153-161

Coffroth MA (1985) Mucous sheet formation on poritid corals: effects of altered salinity and sedimentation. Proc 5th Int Coral Reef Congr, Tahiti 4:165-171

Coffroth MA (1990) Mucous sheet formation on Poritid corals - an evaluation of coral mucus as a nutrient source on reefs. Mar Biol 105:39-49

Coffroth MA (1991) Cyclical mucous sheet formation on poritid corals in the San Blas Islands, Panama. Mar Biol 109: $35-40$

Coles SL, Strathmann R (1973) Observations on coral mucus 'flocs' and their potential trophic significance. Limnol Oceanogr 18:673-678

Cooney RP, Pantos O, Le Tissier MDA, Barer MR, O'Donnell AG, Bythell JC (2002) Characterisation of the bacterial consortium associated with black band disease in coral using molecular microbiological techniques. Environ Microbiol 4:401-413

Cross CE, Halliwell B, Allen A (1984) Antioxidant production - a function of tracheo-bronchial and gastrointestinal mucus. Lancet 1:1328-1330

Crossland CJ (1987) In situ release of mucus and DOC-lipid from the corals Acropora variabilis and Stylophora pistillata in different light regimes. Coral Reefs 6:35-42

Crossland CJ, Barnes DJ, Borowitzka MA (1980) Diurnal lipid and mucus production in the staghorn coral Acropora acuminata. Mar Biol 60:81-90

Dallmeyer DG, Porter JW, Smith GJ (1982) Effects of particulate peat on the behaviour and physiology of the Jamaican reef-building coral Montastraea annularis. Mar Biol 68: 229-233

Daumas R, Thomassin BA (1977) Protein fractions in coral and zoantharian mucus: possible evolution in coral reef environments. Proc 3rd Int Coral Reef Symp 1:517-523

Daumas R, Galois R, Thomassin BA (1982) Biochemical composition of soft and hard coral mucus on a New Caledonian lagoonal reef. Proc 4th Int Coral Reef Symp 2:59-67

Davies PS (1984) The role of zooxanthellae in the nutritional energy requirements of Pocillopora eydouxi. Coral Reefs 2:181-186

Deacon EL (1979) The role of coral mucus in reducing the wind drag over coral reefs. Boundary Layer Meteorol 17: 517-522

Denny MW (1989) Invertebrate mucous secretions: functional alternatives to vertebrate paradigms. In: Chantler E, Ratcliffe NA (eds) Mucus and related topics. Symp Soc Exp Biol XLIII:337-366

Deplancke B, Vidal O, Ganessunker D, Donovan SM, Mackie RI, Gaskins HR (2002) Selective growth of mucolytic bacteria including Clostridium perfringens in a neonatal piglet model of total parental nutrition. Am J Clin Nutr 76: $1117-1125$

Di Salvo LH (1973) Microbial ecology. In: Jones OA, Endean R (eds) Biology and geology of coral reefs, Vol 1. Academic Press, New York, p 1-16

Ding JL, Fung FMY, Ng GWS, Chou LM (1999) Novel bioactivities from a coral Galaxea fascicularis: DNAse-like activity and apoptic activity against a multiple-drugresistant leukemia cell line. Mar Biotechnol 1:328-336
Dixon J, Strugula V, Griffin MD, Welfare MR, Dettmar PW, Allen A, Pearson JP (2001) Esophageal mucin: an adherent mucus gel barrier is absent in the normal esophagus but present in columnar-lined Barrat's esophagus. Am J Gastroenterol 96:2575-2583

Dobretsov S, Qian PY (2004) The role of epibotic bacteria from the surface of the soft coral Dendronephthya sp. in the inhibition of larval settlement. J Exp Mar Biol Ecol 299: $35-50$

Drollet JH, Glaziou, Martin PMV (1993) A study of mucus from the solitary coral Fungia fungites (Scleractinia: Fungiidae) in relation to photobiological UV adaptation. Mar Biol 115:263-266

Drollet JH, Teai T, Faucon M, Martin PMV (1997) Field study of the compensatory changes in UV-absorbing compounds in the mucus of the solitary coral (Fungia repada) (Scleractinia: Fungiidae) in relation to solar UV radiation, seawater temperature, and other coincident physicochemical parameters. Mar Freshw Res 48:329-333

Ducklow HW (1990) The biomass, production and fate of bacteria in coral reefs. In: Dubinsky Z (ed) Ecosystems of the world: coral reefs. Elsevier, Amsterdam, p 265-290

Ducklow HW, Mitchell R (1979a) Composition of mucus released by reef coelenterates. Limnol Oceanogr 24:706-714

Ducklow HW, Mitchell R (1979b) Bacterial populations and adaptations in the mucus layers on living corals. Limnol Oceanogr 24:715-725

Duerden JE (1906) The role of mucus in corals. Q J Microsc Sci 49:591-614

Edmunds PJ, Davies PS (1986) An energy budget for Porites porites (Scleractinia). Mar Biol 92:339-347

Edmunds PJ, Davies PS (1989) An energy budget for Porites porites (Scleractinia), growing in a stressed environment. Coral Reefs 8:37-43

Field JG (1972) Some observations on the release of dissolved organic carbon by the sea urchin Strongylocentrotus droebachiensis. Limnol Oceanogr 17:759-761

Frias-Lopez J, Zerkle AL Bonheyo GT, Fouke BW (2002) Partitioning of bacterial communities between seawater and health, black band diseased, and dead coral surfaces. Appl Environ Microbiol 68:2214-2228

Fung FMY, Ding JL (1998) A novel anitumour compound from the mucus of a coral, Galaxea fascicularis, inhibits topiosomerase I and II. Toxicon 36:1053-1058

Goldberg WM (2002) Feeding behaviour, epidermal structure and mucus cytochemistry of the scleractinian Mycetophyllis reesi, a coral without tentacles. Tissue Cell 34:232-245

Goreau TF (1959) The physiology of skeleton formation in corals. I. a method for measuring the rate of calcium deposition by corals under different light conditions. Biol Bull (Woods Hole) 116:59-75

Gottfried M, Roman MR (1983) Ingestion and incorporation of coral mucus detritus by reef zooplankton. Mar Biol 72: 211-218

Greenwood PG, Garry K, Hunter A, Jennings M (2004) Adaptable defense: a nudibranch mucus inhibits nematocyst discharge and changes with prey type. Biol Bull (Woods Hole) 206:113-120

Grenon JF, Walker G (1980) Biochemical and rheological properties of the pedal mucus of the limpet Patella vulgata. Comp Biochem Physiol B 66:451-458

Griffiths RJ (1977) Thermal stress and the biology of Actinia equina L (Anthozoa). J Exp Mar Biol Ecol 27:141-154

Gutierrez-Rodrigues C, Lasker HR (2004) Reproductive biology, development and planula behaviour in the Caribbean gorgonian Pseudopterogorgia elisabethae. Invertebr Zool 123:54-67 
Harii S, Kayanne H (2003) Larval settlement of corals in flowing water using a racetrack flume. Mar Tech Soc J 36: $76-79$

Harrison PL, Wallace CC (1990) Reproduction, dispersal and recruitment of scleractinian corals. In: Dubinsky Z (ed) Ecosystems of the world: coral reefs. Elsevier, Amsterdam, p 133-207

Hawkridge JM (1998) Physiological and biochemical defences against environmental stressors in cnidarians. $\mathrm{PhD}$ thesis, University of Newcastle

Hayes RL, Goreau NI (1998) The significance of emerging diseases in the tropical coral reef ecosystem. Rev Biol Trop 46:173-185

Hildemann WH, Linthicum DS, Vann DC (1975) Transplantation and immunoincompatability reactions among reefbuilding corals. Immunogenetics 2:269-284

Hildemann WH, Raison RL, Hull CJ, Akaka LK, Okamoto J, Cheung G (1977) Tissue transplantation immunity in corals. Proc 3rd Int Coral Reef Symp 1:537-543

Howard LS, Brown BE (1984) Heavy metals and reef corals. Oceanogr Mar Biol Annu Rev 22:195-210

Howell R (1982) The secretion of mucus by marine nematodes (Enoplus spp): possible mechanism influencing the uptake and loss of heavy metals. Nematologica 28:110-114

Hunt S, Jevons FR (1966) The hypobranchial mucin of the whelk Buccinum undatum L.: the polysaccharide sulphate component. Biochem J 98:522-529

Isa Y, Yamazato K (1981) The ultrastructure of calicoblast and related tissues in Acropora hebes (Dana). Proc 4th Int Coral Reef Symp 2:99-105

Jaap WC, Wheaton J (1975) Observations on Florida reef corals treated with fish collecting chemicals. Fla Mar Res Publ 10:1-7

Jensen PR, Harvell CD, Wirtz K, Fenical W (1996). Antimicrobial activity of extracts of Caribbean gorgonian corals. Mar Biol 125:411-419

Johannes RE (1967) Ecology of organic aggregates in the vicinity of a coral reef. Limnol Oceanogr 12:189-192

Jordan N, Newton J, Pearson J, Allen A (1998) A novel method for the visualisation of the in situ mucus layer in rat and man. Clin Sci 95:97-106

Kellogg CA (2004) Tropical Archaea: diversity associated with the surface microlayer of corals. Mar Ecol Prog Ser 273:81-88

Kelman D, Kushmaro A, Loya Y, Kashman Y, Benayahu Y (1998) Antimicrobial activity of a Red Sea coral Parerythropodium fulvum fulvum: reproductive and developmental considerations. Mar Ecol Prog Ser 169:87-95

Kim K (1994) Antimicrobial activity in gorgonian corals (Coelenterata, Octocorallia). Coral Reefs 13:75-80

Kinchington D (1982) Organic matrix synthesis by scleractinian coral larval and post-larval stages during skeletogenesis. Proc 4th Int Coral Reef Symp 2:107-113

Koh EGL (1997) Do scleractinian corals engage in chemical warfare against microbes? J Chem Ecol 23:379-398

Kojis BL, Quinn NJ (1981) Aspects of sexual reproduction and larval development in the shallow water hermatypic coral, Goniastrea australensis (Edwards and Haime, 1857). Bull Mar Sci 31:558-573

Krupp DA (1982) The composition of the mucus from the mushroom coral Fungia scutaria. Proc 4th Int Coral Reef Symp 2:69-73

Krupp DA (1984) Mucus production by corals exposed during an extreme low tide. Pac Sci 38:1-11

Kushmaro A, Rosenberg E, Fine M, Loya Y (1997) Bleaching of the coral Oculina patagonica by Vibrio AK-1. Mar Ecol Prog Ser 147:159-165
Kushmaro A, Rosenberg E, Fine M, Ben-Haim Y, Loya Y (1998) Effect of temperature on bleaching of the coral Oculina patagonica by Vibrio shiloi AK-1. Mar Ecol Prog Ser 171:131-137

Kwart H, Shashoua VE (1957) The structure and constitution of mucus. Trans NY Acad Sci 19:595-612

Lang JC, Chornesky EA (1990) Competition between scleractinian reef corals - a review of mechanisms and effects. In: Dubinsky Z (ed) Ecosystems of the world: coral reefs. Elsevier, Amsterdam, p 209-252

Le Tissier MDA (1987) The nature and construction of skeletal spines in Pocillopora damicornis (Linnaeus). PhD thesis, University of Newcastle

Lewis JB (1977) Suspension feeding in Atlantic reef corals and the importance of suspended particulate matter as a food source. Proc 3rd Int Coral Reef Symp 1:405-408

Lewis JB, Price WS (1975) Feeding mechanisms and feeding strategies of Atlantic reef corals. J Zool Lond 176:527-544

Linley EAS, Koop K (1986) Significance of pelagic bacteria as a trophic resource in a coral reef lagoon, One Tree Island, Great Barrier Reef. Mar Biol 92:457-464

Lipp EK, Jarrell JL, Griffin DW, Lukasik J, Jaculiewicz J, Rose JB (2002) Preliminary evidence for human fecal contamination of corals in the Florida keys, USA. Mar Pollut Bull 44:666-670

Llewellyn M, Qureshi AL (1979) The energetics of Megoura viciae reared on different parts of the broad bean plant (Vicia faba). Ent Exp Appl 26:127-135

Marin F, Smith M, Yeishin I, MuyzerG, Westbroek P (1996) Skeletal matrices, muci and the origin of invertebrate calcification. Proc Natl Acad Sci USA 93:1554-1559

Marshall AT (2002) Occurrence, distribution and localisation of metals in cnidarians. Microsc Res Tech 56:341-357

Marshall AT, Clode P (2004) Effects of calcium-free and low calcium artificial sea water on polyps of a scleractinian coral Galaxea fascicularis. Coral Reefs 23:277-280

Marshall AT, Wright OP (1991) Freeze-substitution of scleractinian coral for confocal scanning laser microscopy and X-ray microanalysis. J Microsc 162:341-354

Marshall AT, Wright OP (1993) Confocal laser scanning light microscopy of the extra-thecal epithelia of undecalcified scleractinian corals. Cell Tissue Res 272:533-543

Marshall AT, Wright OP (1995) X-ray microanalysis of coral mucus. Microbeam Anal 4:305-315

Marshall S, Orr AP (1931) Sedimentation on Low Isles reef and its relation to coral growth. Sci Rep Great Barrier Reef Exped 1:94-133

Marshall S, Stephenson TA (1933) The breeding of reef animals. Part I. The corals. Sci Rep Great Barrier Reef Exped III:219-245

Means JC, Sigleo AC (1986) Contribution of coral reef mucus to the colloidal organic pool in the vicinity of Discovery Bay, Jamaica, W.I. Bull Mar Sci 39:110-118

Meesters EH, Moordeloos M, Bak RPM (1994) Damage and regeneration-links to growth in the reef coral Montastrea annularis. Mar Ecol Prog Ser 112:119-128

Meesters EH, Wesseling I, Bak RPM (1996) Partial mortality in 3 species of reef-building corals and the relation with coral mortality. Bull Mar Sci 58:838-852

Meesters EH, Pauchli W, Bak RPM (1997) Predicting regeneration of physical damage on a reef-building coral by regeneration capacity and lesion shape. Mar Ecol Prog Ser 146:91-99

Meikle P, Richards GN, Yellowlees D (1987) Structural determination of the oligosaccharide side-chains from a glycoprotein isolated from the mucus of the coral Acropora formosa. J Biol Chem 262:16941-16947 
Meikle P, Richards GN, Yellowlees D (1988) Structural investigations on the mucus from 6 species of coral. Mar Biol 99: 187-193

Mills MM, Sebens KP (1997) Particle ingestion efficiency of the coral Siderastrea siderea and Agaricia agaricites: effects of flow speed and sediment load. Proc 8th Int Coral Reef Symp 2:1059-1064

Mitchell R, Chet I (1975) Bacterial attack of corals in polluted water. Microb Ecol 2:227-233

Moriarty DJW, Pollard PC, Hunt WG (1985) Temporal and spatial variation in bacterial production in the water column over a coral reef. Mar Biol 85:285-292

Muscatine L, Falkowski PG, Porter JW, Dubinsky Z (1984) Fate of photosynthetic fixed carbon in light- and shadeadapted colonies of the symbiotic coral Stylophora pistillata. Proc R Soc Lond B 222:181-202

Neff JM, Anderson JW (1981) Responses of marine animals to petroleum and specific petroleum hydrocarbons. Appl Science Publ, London, p 117-121

Neudecker S (1983) Growth and survival of scleractinian corals exposed to thermal effluents at Guam. Proc 4th Int Coral Reef Symp 1:173-180

Oren U, Rinkevich B, Loya Y (1997) Orientated intra-colonial transport of ${ }^{14} \mathrm{C}$ labeled materials during coral regeneration. Mar Ecol Prog Ser 161:117-122

Pascal H, Vacelet E (1981) Bacterial utilization of mucus on the coral reef of Aqaba (Red Sea). Proc 4th Int Coral Reef Symp 1:669-677

Paul JH, DeFlaun MF, Jeffrey WH (1986) Elevated levels of microbial activity in the coral surface microlayer. Mar Ecol Prog Ser 33:29-40

Peters EC (1997) Diseases of coral reef organisms. In: Birkeland C (ed) Life and death of coral reefs. Chapman \& Hall, New York, p 114-139

Peters EC, Meyers PA, Yevich PP, Blake NJ (1981) Bioaccumulation and histopathological effects of oil on a stony coral. Mar Pollut Bull 12:333-339

Porchet N, Aubert JP (2004) MUC genes: mucin or not mucin? That is the question. MS Med Sci 20:569-574

Porter JW, Dustan P, Jaap WC, Patterson KL, Kosmynin V, Meier OW, Patterson ME, Parsons M (2001) Patterns of spread of coral disease in the Florida Keys. Hydrobiologia 460:1-24

Reigl B, Branch GM (1995) Effects of sediment on the energy budgets of four scleractinian (Bourne 1900) and five alcyonacean (Lamouroux 1816) corals. J Exp Mar Biol Ecol 186:259-275

Richman S, Loya Y, Slobodkin LB (1975) The rate of mucus production by corals and its assimilation by the coral reef copepod Acartia negligens. Limnol Oceanogr 20:918-923

Ritchie KB, Smith GW (2004) Microbial communities of coral surface mucopolysaccharide layers. In: Rosenberg E, Loya $\mathrm{Y}$ (eds) Coral health and disease. Springer-Verlag, New York, p 259-264

Rogers CS (1990) Responses of coral reefs and reef organisms to sedimentation. Mar Ecol Prog Ser 62:185-202

Rohwer F, Kelley S (2004) Culture independent analyses of coral associated microbes. In: Rosenberg E, Loya Y (eds) Coral health and disease. Springer-Verlag, New York, p 265-278

Ronkin RR (1955) Some physico-chemical properties of mucus. Arch Biochem Biophys 56:76-89

Rosenberg E, Ben-Haim Y (2002) Microbial diseases of corals and global warming. Environ Microbiol 4:318-326

Ross SM, Corrsin S (1974) Results of an analytical model of muco-ciliary pumping. J Appl Physiol 37:333-339

Rublee PA, Lasker HR, Gottfried M, Roman MR (1980) Pro- duction and bacterial colonization of mucus from the soft coral Briarum asbestinum. Bull Mar Sci 30:888-893

Santavy DL, Peters EC (1997) Microbial pests: coral disease research in the western Atlantic. Proc 8th Int Coral Reef Symp 1:607-612

Sauer KP, Muller M, Weber M (1986) Alloimmune memory for glycoproteid recognition molecules in sea anemones competing for space. Mar Biol 92:73-79

Schumacher H (1977) Ability in fungiid corals to overcome sedimentation. Proc 3rd Int Coral Reef Symp 1:503-509

Segel A, Ducklow WH (1982) A theoretical investigation into the influence of sublethal stresses on coral-bacterial ecosystem dynamics. Bull Mar Sci 32:919-935

Shick JM (1991) A functional biology of sea anemones. Chapman \& Hall, New York

Shick JM, Lesser MP, Dunlap WC, Stochaj WR, Chalker BC, Wuwon J (1995) Depth-dependent responses to solar ultraviolet radiation and oxidative stress in the zooxanthellate coral (Acropora microphthalma). Mar Biol 122:41-51

Shick JM, Lesser MP, Jokiel PL (1996) Effects of ultraviolet radiation on corals and other coral reef organisms. Global Change Biol 2:527-545

Slattery M, McClintock JB, Heine JN (1995) Chemical defences in Antarctic soft corals: evidence for anti-fouling compounds. J Exp Mar Biol Ecol 190:61-77

Slattery M, Hamann MT, McClintock JB, Perry TL, Puglisi MP, Yoshida WY (1997) Ecological roles for water-borne metabolites from Antarctic soft corals. Mar Ecol Prog Ser 161:133-144

Sleigh MA (1989) Adaptations of ciliary systems for the propulsion of water and mucus. Comp Biochem Physiol A 94:359-364

Sleigh MA, Blake JR, Liron N (1988) The propulsion of mucus by cilia. Am Rev Resp Dis 137:726-741

Sorokin YI (1973) On the feeding of some scleractinian corals with bacteria and dissolved organic matter. Limnol Oceanogr 18:380-385

Sorokin YI (1978) Microbial production in the coral reef community. Arch Hydrobiol 83:281-323

Spungin B, Silberberg A (1984) Stimulation of mucus secretion, ciliary activity and transport in frog palate epithelium. Am J Physiol C 247:299-308

Stafford-Smith MG (1993) Sediment-rejection efficiency of 22 species of Australian scleractinian corals. Mar Biol 115: $229-243$

Stafford-Smith MG, Ormond RFG (1992) Sediment-rejection mechanisms of 42 species of Australian scleractinian corals. Aust J Mar Freshw Res 43:683-705

Strugula V, Allen A, Dettmar PW, Pearson JP (2003) Colonic mucin: methods of measuring mucus thickness. Proc Nutr Soc 62:237-243

Sutherland KP, Porter JW, Torres C (2004) Disease and immunity in Caribbean and Indo-Pacific zooxanthellate corals. Mar Ecol Prog Ser 266:273-302

Taylor C, Allen A, Dettmar PW, Pearson JP (2003) The gel matrix of gastric mucus is maintained by a complex interplay of transient and non-transient associations. Biomacromolecules 4:922-927

Teai T, Drollet JH, Bianchini JP, Cambon A, Martin PMV (1997) Widespread occurrence of mycosporine-like amino acid compounds in scleractinians from French Polynesia. Coral Reefs 16:169-176

Thompson JH, Shinn EA, Bright TJ (1980) Effects of drilling mud on seven species of reef-building corals as measured in the field and laboratory. Elsevier Oceanogr Ser A 27: 433-453

Toren A, Lanndau L, Kushmaro A, Loya Y, Rosenburg E 
(1998) Effect of temperature on adhesion of Vibrio strain AK-1 to Oculina patagonica and on coral bleaching. Appl Environ Microbiol 64:1379-1384

Tranter PRG, Nicholson DN, Kinchington D (1982) A description of the spawning and post-gastrula development of the cool temperate coral Caryophyllia smithii (Stokes and Broderip). J Mar Biol Assoc UK 62:845-854

Trench RK (1974) Nutritional potential in Zoanthus sociatus (Coelenterata, Anthozoa). Helgol Wiss Meeresunters 26: 174-216

Vacelet E, Thomassin BA (1991) Microbial utilization of coral mucus in long-term in situ incubation over a coral-reef. Hydrobiologia 211:19-32

Verdugo P (1990) Goblet cells secretion and mucogenesis. Annu Rev Physiol 52:157-176

Wallace C (1999) Staghorn corals of the world. CSIRO, Collingwood

Wild C, Huettel M, Klueter A, Kremb SG, Rasheed MYM,

Editorial responsibility: Otto Kinne (Editor-in-Chief),

Oldendorf/Luhe, Germany
Jorgensen BB (2004a) Coral mucus functions as an energy carrier and particle trap in the reef ecosystem. Nature 428: 66-70

Wild C, Rasheed M, Werner U, Franke U, Johnstone R, Huettel M (2004b) Degradation and mineralization of coral mucus in reef environments. Mar Ecol Prog Ser 267: 159-171

Williams GB (1965) Observations on the behaviour of the planulae larvae of Clava squamata. J Mar Biol Assoc UK 45:257-273

Woollcott TG (1973) Physiological ecology and intertidal zonation in limpets (Acmaea): a critical look at limiting factors. Biol Bull (Woods Hole) 145:389-422

Yonge CM (1930) Studies on the physiology of corals. 1. Feeding mechanisms and food. Sci Rep Great Barrier Reef Exp $1: 13-57$

Yonge CM (1940) The biology of reef-building corals. Sci Rep Great Barrier Reef Exp 1:353-391

Submitted: December 9, 2004; Accepted: March 8, 2005

Proofs received from author(s): June 24, 2005 